
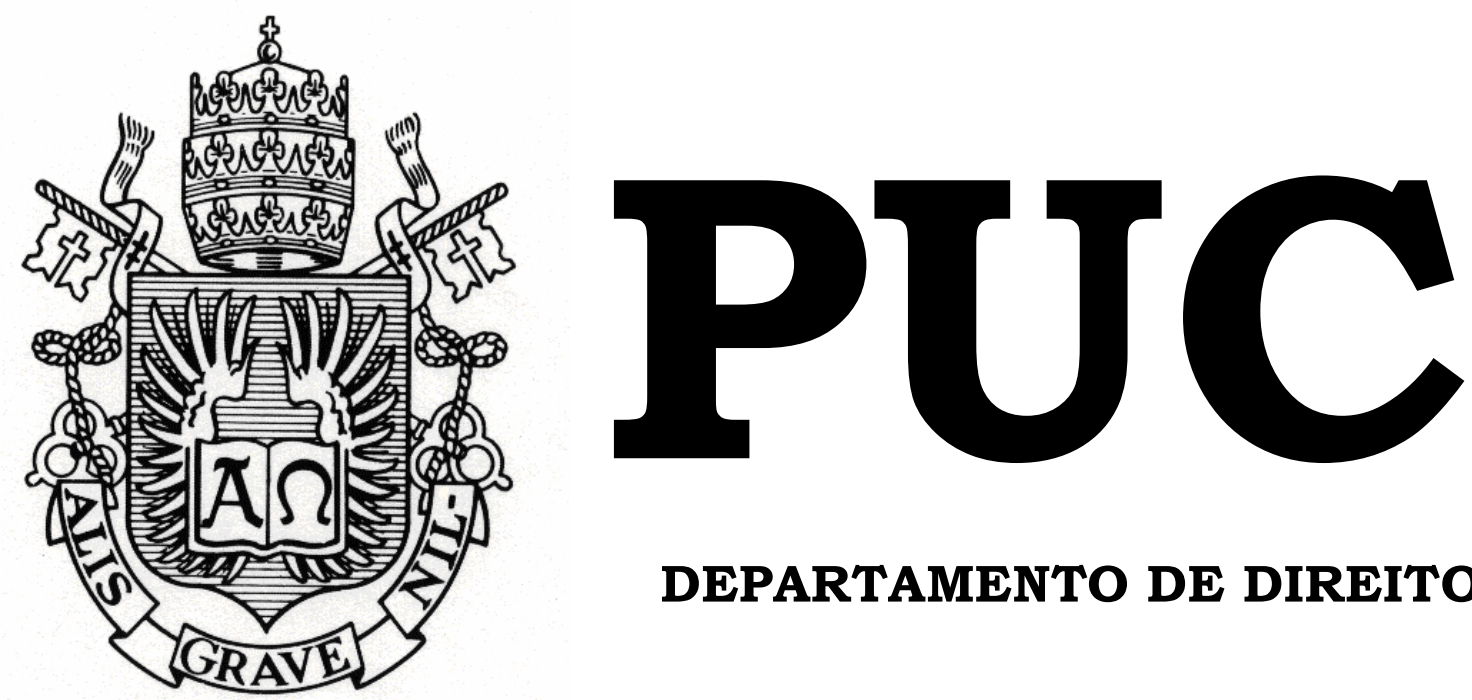

DEPARTAMENTO DE DIREITO

O Principio da Legalidade e sua aplicação no artigo 149 do Código Penal após a Lei $10.803 / 2003$

\author{
por \\ LUÍSA SERTÃ DE SOUZA CARVALHO
}

ORIENTADOR(A): Agnes Christian Chaves Faria 2014.2

PONTIFÍCIA UNIVERSIDADE CATÓLICA DO RIO DE JANEIRO

RUA MARQUÊS DE SÃO VICENTE, 225 - CEP 22453-900

RIO DE JANEIRO - BRASIL 


\title{
O Princípio da Legalidade e sua aplicação no artigo 149 do Código Penal após a Lei $10.803 / 2003$
}

\author{
por \\ LUÍSA SERTÃ DE SOUZA CARVALHO \\ Monografia apresentada \\ ao Departamento de \\ Direito da Pontificia \\ Universidade Católica do \\ Rio de Janeiro (PUC-Rio) \\ para a obtenção do Título \\ de Bacharel em Direito. \\ Orientador(a): Agnes \\ Christian Chaves Faria
}


Ao meu avô, Roberto Sertã, pelo exemplo de pessoa a se tornar, eternas saudades.

À minha avó,Vilma Sertã, maior madrinha e companheira imaginável.

À minha mãe, Mônica Sertã, eterna protetora.

Ao meu pai, Carlos Eduardo Carvalho, por me ensinar o perdão e a superação.

Ao meu irmão, pelas risadas no dia-a-dia.

À Iaia, pelas lições inesquecíveis da minha "mãe preta".

À Tia Vivien, segunda mãe, fonte de inspiração e alegria.

Aos amigos Ana Cecília, Caroline, Débora, Isadora, Maria Lúcia e Savigny por me proporcionarem 5 anos maravilhosos.

Às minhas irmãs de coração, Maria Eduarda e Maria Clara, pela simples, porém, essencial existência. 


\section{Agradecimentos}

Agradeço à minha orientadora, professora e amiga, Agnes, pelo carinho, atenção e motivação para a realização do presente trabalho.

Agradeço aos companheiros de CAEL que, por meio dos ideais da eterna Contra Corrente, abriram meus olhos para uma realidade até então não vivenciada, expandiram os meus horizontes e me proporcionaram momentos inesquecíveis. Sem vocês, a PUC não teria graça.

Agradeço à amiga Júlia Gitirana, pelo exemplo de mulher e de vida. Você é fonte de inspiração.

Agradeço ao fiel companheiro Luiz Fernando, pelo carinho, atenção e parceria durante os anos de PUC e estágio no Fragoso Advogados.

Agradeço aos amigos de longa data, Cláudio Paes Lemes (Claudião) Eduardo e Luiz Eduardo Shalders, Juliana Faoro, Maria Gabriella Baeta Neves, Maria Eduarda Bellotti, pela ajuda na formação dos meus ideais e valores.

Agradeço ao amigo Tomás Ribas, pelas danças sem música pelo Centro do Rio de Janeiro, repletas de alegria.

Agradeço ao amigo Rodrigo Rosso, pela companhia, abraços e palavras de carinho e suporte, sempre. 
Agradeço a todos os amigos que, agregaram valor ao meu aprendizado durante a faculdade e fizeram de mim a pessoa que hoje me tornei.

Agradeço aos meus chefes, Marcelo Machado, Leonardo Salgueiro e Ana Lúcia Paim Sérgio, pela paciência e confiança em mim depositadas, os ensinamentos de vocês ficarão para sempre. 


\section{Palavras chaves}

CP - Código Penal.

CR-Constituição da República.

STF - Supremo Tribunal Federal

STJ - Superior Tribunal de Justiça

TRF - Tribunal Regional Federal

OIT - Organização Internacional do Trabalho

Inq - Inquérito

RExt - Recurso Extraordinário

Apel.Crim.- Apelação Criminal 


\section{Resumo}

O presente trabalho tem como objetivo analisar aspectos do princípio da legalidade e a sua aplicação após da mudança realizada pela lei 10.803/2003 no Código Penal de 1940.

Tem como principal objetivo demonstrar que, o princípio da legalidade tem que ser aplicado nos casos em que a conduta alvo de investigação ou acusação for anterior ao ano de 2003, ou seja, anterior à lei supramencionada. 


\section{Sumário}

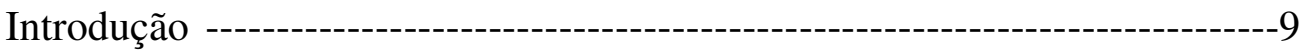

Capítulo 1 - O Princípio da Legalidade ------------------------------------------11

1.1 - O contexto de criação do Princípio da Legalidade --------------------11

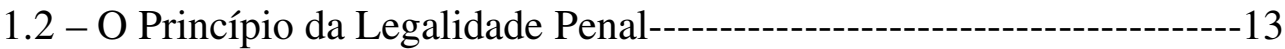

1.2.1 - O princípio da Anterioridade e da Irretroatividade Penal. -----------14

1.2.2 - O princípio da Taxatividade-----------------------------------------------16

Capítulo 2 - Do crime de redução à condição análoga à de escravo.--------18

2.1 - Da evolução histórica da tipificação do crime de redução à condição análoga à de escravo. ---------------------------------------------------------------18

2.2-O tipo penal do artigo 149 e sua interpretação antes da alteração realizada pela Lei 10.803 de Dezembro de 2003-------------------------------21

2.2.1 - O tipo penal aberto de 1950 e o tipo penal criado pela nova lei. ---23

2.3- As mudanças trazidas pela Lei 10.803 de dezembro de 2003 ----------25

2.3.1-Da mudança da competência para julgar a conduta tipificada do artigo 149 do Código Penal e outras mudanças.---------------------------------------26

Capítulo 3- A aplicação do princípio da Legalidade em casos anteriores às mudanças da Lei - Casos concretos.

$-31$

3.1 Quando o sujeito ativo restringiu a liberdade de locomoção do sujeito passivo. 
3.2 - Quando o sujeito ativo não restringiu a liberdade de locomoção do sujeito passivo, porém o último trabalhou em condições degradantes. -----32

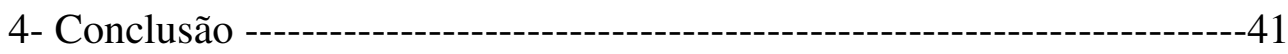

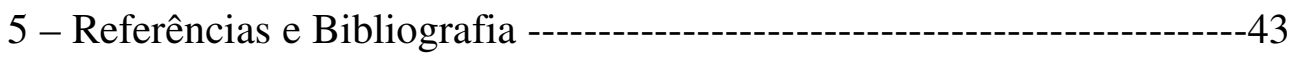




\section{Introdução}

O presente trabalho tem como objetivo analisar a aplicação do princípio da legalidade e seus desdobramentos na mudança que a lei 10.803, de 11 de dezembro de 2003 acarretou no tipo penal do artigo 149 do Código Penal Brasileiro, visando demonstrar que antes da mencionada lei, o entendimento para a consumação do delito era restrito à privação de liberdade e, somente com a nova lei, novas condutas foram tipificadas, como: "submetendo-o a trabalhos forçados ou a jornada exaustiva, quer sujeitando-o a condições degradantes de trabalho, quer restringindo, por qualquer meio, sua locomoção em razão de dívida contraída com o empregador ou preposto."

Grande discussão na doutrina e na jurisprudência existe acerca do tema aqui tratado, vez que metade dos doutrinadores argumentam que a mudança trazida pela lei 10.803/2003 é de natureza explicativa, ou seja, não incluiria novas condutas ao tipo, de modo que o princípio da legalidade mais especificamente o princípio da irretroatividade da lei penal - não pode ser aplicado nos casos ocorridos antes da lei em questão.

O Princípio da Legalidade, ou Princípio da Reserva Legal é o princípio que rege as normas do Direito Penal Brasileiro, tal é sua importância, que o mesmo encontra-se previsto expressamente na Constituição da República no capítulo das garantias individuais, no artigo $5^{\circ} \mathrm{XXXIX}^{1}$, bem como possui um artigo próprio no código penal qual seja, $\operatorname{artigo1^{\circ }.}$

\footnotetext{
${ }^{1}$ Art. $5^{\circ}, \mathrm{CR}$ - Todos são iguais perante a lei, sem distinção de qualquer natureza, garantindo-se aos brasileiros e aos estrangeiros residentes no País a inviolabilidade do direito à vida, à liberdade, à igualdade, à segurança e à propriedade, nos termos seguintes:

(...)

XXXIX - não há crime sem lei anterior que o defina, nem pena sem prévia cominação legal.

${ }^{2}$ Art. $1^{\circ} \mathrm{CP}$ - Não há crime sem lei anterior que o defina. Não há pena sem prévia cominação legal
} 
Em uma análise sobre o princípio da legalidade, podemos extrair o princípio da anterioridade da lei penal e o princípio da retroatividade da lei penal benéfica que pode ser denominado também de princípio da irretroatividade da lei penal.

Portanto, o presente trabalho pretende por meio de uma análise de doutrinadores,julgados anteriores a mudança da lei e casos concretos, demonstrar que o intuito do legislador com a mudança da lei 10.803/2003 era de criar um novo tipo penal para o artigo 149. Consequentemente, deve ser aplicado o princípio da legalidade nos casos ocorridos antes da mudança da lei, de maneira a absolver os réus cuja conduta anterior à lei consistia em oferecer condições degradantes de trabalho, porém não privação da liberdade da suposta vítima. 


\section{Capítulo 1 - O Princípio da Legalidade}

\section{1 - 0 contexto de criação do Princípio da legalidade}

Os conceitos de Princípio da Legalidade e o Estado Democrático de Direito estão intimamente ligados, vez que, para que seja implementado um Estado democrático de direito, é necessário que os cidadãos tenham seus direitos protegidos da arbitrariedade do governante e tenham conhecimento pleno das condutas que são criminalmente reprováveis.

O princípio da legalidade é criado com essa função, modo à restringir o poder do governante e limitá-lo ao que está disposto na lei, de modo à trazer para a população o sentimento de segurança e a certeza de que um cidadão somente poderá ser punido pelas condutas determinadas em lei. Nas palavras do professor Pedro Lenza:

“O princípio da legalidade surgiu com o Estado de Direito, opondo-se a toda e qualquer forma de poder autoritário, antidemocrático.”3

Nesse sentido, podemos nos utilizar da lição de Paulo Bonavides para entender e analisar a necessidade da criação do princípio aqui estudado:

“O princípio da legalidade nasceu do anseio de estabelecer na sociedade humana regras permanentes e válidas, que fossem obras da razão, e pudessem abrigar os indivíduos de uma conduta arbitrária e imprevisível da parte dos governantes. Tinha-se em vista alcançar um estado geral de confiança e certa na ação dos titulares do poder, evitando-se assim a dúvida, a intranquiilidade, a desconfiança e a suspeição, tão usuais onde o poder é absoluto, onde o governo de acha dotado

\footnotetext{
${ }^{3}$ LENZA. Pedro. .Direito Constitucional esquematizado. 16a Edição. São Paulo. Editora Saraiva. 2012, pág 978
} 
de uma vontade pessoal soberana ou se reputa legibus solutus e onde, enfim, as regras de convivência não foram previamente elaboradas e nem reconhecidas."

Doutrinadores atribuem a origem desse princípio à Carta Magna Inglesa de $1215^{5}$, que em seu artigo 39 possuía a seguinte redação:

"Nenhum homem livre será detido, nem preso, nem despojado de sua propriedade, de suas liberdades ou livres usos, nem posto fora da lei, nem exilado, nem perturbado de maneira alguma; e não poderemos, nem faremos pôr a mão sobre ele, a não ser em virtude de um juízo legal de seus pares e segundo as leis do País."

Apesar de sua primeira manifestação ter sido em 1215, como mencionado acima, foi no Liberalismo que o princípio se assentou, pois “tornou possível uma limitação do poder punitivo - e, especialmente impositivo - do Estado e, especialmente, impositivo - do Estado e, com isto, a segurança da liberdade individual." 6

Nesse sentido, merece também destaque a Teoria do Contrato Social, apresentada por Jacques Rousseau. De acordo com a mesma, "o cidadão só aceita viver em sociedade com a criação de garantias mínimas contra o arbítrio do Estado, prevendo, inclusive, regras sobre imposições de punições objetivas e impessoais, previamente delimitadas sob o prisma da legalidade estrita." 7

\footnotetext{
${ }^{4}$ BONAVIDES, Paulo. Ciência política. São Paulo: Editora Malheiros, 1994, pág: 112.

${ }^{5}$ NORONHA, E. Magalhães. Direito Penal v.1. Introdução e Parte Geral. 29. ed. São Paulo: Saraiva, 1991, p. 67.

GRECO. Rogério. Curso de Direito Penal. 14 ${ }^{\mathrm{a}}$ Edição. Rio de Janeiro. Editora Impetus. 2012, pág 94.

${ }^{6}$ ROXIN, Claus. ARTZ,G., e TIEDEMANN, K. Introducción al Derecho Penal y al Derecho Procesal Penal. Barcelona, Ariel,1989, pág. 73.

${ }^{7}$ ROUSSEAU. Jean-Jacques. Do Contrato Social. Edição Ridendo Castigat Mores. Pág.30. Fonte Digital: www.jahr.org .
} 
Após a Teoria do Contrato Social apresentada por Rousseau em 1762, podemos verificar a presença do princípio da legalidade da condecorada obra de Cesare Beccaria, Dos delitos e das penas.

Nesta obra, Beccaria defende a idéia de que somente através de leis, elaboradas por um legislador, legitimamente eleito, ou seja, que represente o interesse popular, pode determinar delitos e penas.

O princípio da legalidade foi consagrado formalmente na Declaração de Direitos do Homem, de 26 de agosto de 1789 em seu artigo $8^{\circ}$ :

“Art. 8. ${ }^{\circ}$ A lei apenas deve estabelecer penas estrita e evidentemente necessárias e ninguém pode ser punido senão por força de uma lei estabelecida e promulgada antes do delito e legalmente aplicada."

No Brasil, temos o princípio da legalidade da primeira vez manifestado na Constituição da República de 1824, no seu artigo $171^{8}$ e, atualmente o mesmo encontra-se tutelado no artigo $5^{\circ}$ XXXIX da Constituição Federal de $1988^{9}$.

\section{2 - O Princípio da Legalidade Penal}

O Princípio da legalidade penal é um dos mais importantes, senão o mais importante, princípio do Direito Penal. Ele encontra-se tutelado no inciso XXXIX do artigo $5^{\circ}$ da Constituição Federal, trazendo com si a interpretação de que "a lei é a única fonte do Direito Penal quando se quer

\footnotetext{
${ }^{8}$ Art. 171. Todas as contribuições directas, á excepção daquellas, que estiverem applicadas aos juros, e amortisação da Divida Publica, serão annualmente estabelecidas pela Assembléa Geral, mas continuarão, até que se publique a sua derogação, ou sejam substituidas por outras.

${ }^{9}$ Art. $5^{\text {o }}$ Todos são iguais perante a lei, sem distinção de qualquer natureza, garantindo-se aos brasileiros e aos estrangeiros residentes no País a inviolabilidade do direito à vida, à liberdade, à igualdade, à segurança e à propriedade, nos termos seguintes:

XXXIX - não há crime sem lei anterior que o defina, nem pena sem prévia cominação legal;
} 
proibir ou impor condutas sob a ameaça de sanção. Tudo o que não foi expressamente proibido é lícito em Direito Penal."10

A primeira conseqüência do princípio da legalidade penal é a necessidade de uma lei, strictu senso, para a criação de delitos, formulação ou agravamento de penas. A segunda conseqüência é a impossibilidade de criação de delitos e de penas pelos costumes, ${ }^{11}$ isso porque os costumes não são fontes normativas do direito penal. No entanto, eles devem ser utilizados pelo órgão aplicador do direito para valorar certos conceitos, como, por exemplo, os conceitos de ato obsceno (artigo 233 do $\mathrm{CP}^{12}$ ).

\subsection{1 - O Princípio da Anterioridade e da Irretroatividade Penal.}

Os Princípios da Anterioridade e da irretroatividade penal são princípios que derivam do Princípio da Legalidade, possuindo amparo legal nos incisos XXXIX e XL da Constituição Brasileira.

De acordo com o doutrinador Aníbal Bruno, dentre as diversas funções que o princípio da legalidade exerce, destaca-se a função trazida pelo princípio da irretroatividade: “(...) então o princípio se opõe à retroatividade da norma penal incriminadora, trazendo a necessária precisão e segurança ao Direito (...)."13

O Princípio da anterioridade penal consiste na garantia de que ninguém será condenado sem lei anterior regularmente elaborada que

\footnotetext{
${ }^{10}$ GRECO, Rogério. Curso de Direito Penal. $2^{\text {a }}$ Edição. Rio de Janeiro. Editora Impetus. 2003, pág 104.

11 SANTORO FILHO, Antonio Carlos. Fundamentos de Direito Penal. São Paulo. Malheiros Editora, 2003, pág 57.

12 Art. 233,CP-- Praticar ato obsceno em lugar público, ou aberto ou exposto ao público:

Pena - detenção, de três meses a um ano, ou multa.

${ }^{13}$ BRUNO, Aníbal. Direito Penal v.1. Parte Geral. 3. ed. Rio de Janeiro: Forense, 1978, p. 208.
} 
tipifique a conduta praticada como crime. Esse princípio é "a garantia de que o princípio da legalidade terá o mínimo de eficácia”, tendo em vista que "a criação de leis penais incriminadoras que pudessem retroagir para envolver fatos ocorridos antes de seu advento esvaziaria por completo a garantia constitucional da legalidade penal.". ${ }^{14}$

Complementando o princípio da anterioridade, o princípio da irretroatividade penal consiste na idéia de que a lei penal não deverá retroagir, salvo quando a lei posterior for mais benéfica ao réu. Esse princípio encontra amparo no artigo $2^{\circ}$ do Código Penal e foi criado porque o Direito Penal, como ramo diferenciado do direito, tinha que garantir que em caso de um agravamento de pena ou criação de novo tipo, o réu não poderia ser condenado por lei posterior.

Podemos dizer então que "como consequência necessária do princípio da legalidade, ficam eliminadas as chamadas leis ex post fato" ${ }^{\text {"15, }}$ somente podendo então alguém ser punido por lei anterior à conduta praticada.

Ilustrando o princípio da irretroatividade, diz o Doutrinador Guilherme de Souza Nucci, que “ como regra, que a lei penal não poderá retroagir, mas como exceção, a retroatividade da lei benéfica ao réu ou condenado". ${ }^{16}$ Elucida ainda mais artigo ao trazer seu significado, dizendo que o mesmo "significa que uma lei penal incriminadora somente pode ser aplicada a um fato concreto, caso tenha tido origem antes da prática da conduta para a qual se destina." ${ }^{, 17}$;

\footnotetext{
${ }^{14}$ NUCCI, Guilherme de Souza. Manual de Direito penal:parte geral:parte especial. $7^{a}$ edição. São Paulo. Editora Revista dos Tribunais. 2011. pág 102

15 ZAFFARONI, Eugenio Raúl; PIERANGELI, José Henrique. Manual de Direito Penal Brasileiro: Parte Geral. 5. ed. rev. e atual. São Paulo: Revista dos Tribunais, 2004. p. 218.

${ }^{16}$ NUCCI, Guilherme de Souza. Manual de Direito Penal. $7^{\text {a }}$ Edição. Editora Revista dos Tribunais. 2011, pág 85.

${ }^{17}$ Idem.
} 


\subsection{2 - O Princípio da Taxatividade}

Também chamado como princípio da tipicidade por Antonio Carlos Santoro Filho ${ }^{18}$, o princípio da taxatividade é, assim como o Princípio da irretroatividade e da anterioridade da lei penal, um subprincípio do Princípio da Legalidade.

Conhecido também por meio da expressão latina "Nullum Crimen Nulla Poena Sine Lege Stricta”, esse princípio consiste na idéia de que, não basta a existência de uma lei incriminadora em sentido vago, devendo o legislador, na previsão dos delitos, determiná-los por meio de tipos penais, descrevendo-os de modo certo e inconfundível. ${ }^{19}$

Nesse sentido, podemos observar as lições de Roxin:

"Uma lei indeterminada ou imprecisa e, por isso mesmo, pouco clara não protege o cidadão da arbitrariedade, porque não implica uma autolimitação do ius puniendi estatal, ao qual se possa recorrer. Ademais, contraria o princípio da divisão dos poderes, porque permite ao juiz realizar a interpretação que quiser, invadindo, dessa forma, a esfera do legislativo. ${ }^{20}$

\footnotetext{
18 "A taxatividade, que preferimos denominar de princípio da tipicidade, implica que, para ser plenamente atendido o princípio da legalidade, não basta a existência de uma lei incriminadora em sentido vago, devendo o legislador, na previsão de delitos, determiná-los por meio de tipos penais, descrevendo-os de modo certo e inconfundível" SANTORO FILHO,Antonio Carlos. Fundamentos de Direito Penal. Introdução Crítica, Aplicação da Lei Penal e Teoria do Delito. Editora Malheiro Editores. São Paulo.2003, págs: 60 e 61.

${ }^{19}$ LOPES, Maurício Antônio Ribeiro. Princípio da Legalidade Penal. São Paulo. Editora RT. 1994. pág 128.

${ }^{20}$ ROXIN, 1997 apud BITENCOURT, Cezar Roberto. Tratado de Direito Penal: Parte Geral 1. 14.ed. São Paulo: Saraiva, 2009, p. 11
} 
O princípio da taxatividade tem dois objetivos principais: numa primeira análise, ele visa obrigar o legislador a não produzir normas genéricas, ou seja, busca compelir o legislador a determinar de maneira mais certa, caracterizada e definida a conduta que está sendo incriminada, de modo à "enunciar com clareza os atributos essenciais da conduta humana de forma a torná-la inconfundível com outra."21 Numa segunda análise, objetivo é garantir que o órgão julgador fique limitado à condenar o réu pelo tipo penal descrito, não podendo o mesmo alargá-lo, em hipótese alguma, de modo a prejudicar o réu.

A respeito da importância do princípio da taxatividade num Estado Democrático de Direito, o Procurador Paulo Queiroz diz:

"A máxima taxatividade possível e de real vinculação do juiz à lei é, como diz Sílva Sánchez, um objetivo irrenunciável para o direito penal de um Estado Democrático de Direito, que implica a máxima precisão das mensagens do legislador e a máxima vinculação do juiz a tais mensagens quando das suas decisões, motivo pelo qual se trata de um princípio de legitimação democrática das intervenções penais como garantia da liberdade dos cidadãos derivada do princípio da divisão de poderes.",22

Nesse sentido, podemos observar que o princípio da legalidade e os princípios que dele derivam estão intimamente ligados ao Estado Democrático de Direito brasileiro, de modo que, a desobservância de qualquer um deles significa uma afronta direta ao mesmo.

\footnotetext{
${ }^{21}$ LOPES, Maurício Antônio Ribeiro. Princípios Penais Constitucionais: O Sistema das Constantes Constitucionais. RT, Fascículos Penais, Ano 89, v. 779. RT: São Paulo. 2000.

${ }^{22}$ QUEIROZ.Paulo. Curso de Direito Penal. Volume 1. Parte Geral. Editora Juspodivm. 2013, pág 75.
} 


\section{Capítulo 2 - Do crime de Redução à condição análoga à de escravo.}

\section{1 - Da evolução histórica da tipificação do crime de redução à condição análoga à de escravo.}

$\mathrm{O}$ crime de redução à condição análoga à de escravo pela primeira vez verificada no Código Criminal do Império que, em 1830, tutelava apenas a redução de pessoa livre à condição análoga à de escravo. ${ }^{23}$.

Cezar Bittencourt disserta brevemente sobre o assunto, dizendo que a redação do referido Código carecia de técnica, vez que confundia a situação jurídica que é a escravidão com a situação fática que é alguém ser reduzido a condição semelhante à de escravo. ${ }^{24}$

A escravidão somente voltou a ser alvo de tutela criminal com o Código Penal de 1940, isto porque mesmo tendo o Código Penal de $1890^{25}$ sido promulgado após a abolição da escravatura, silenciou-se acerca do tema. Da mesma maneira ocorreu na Consolidação de Leis penais de 1932, também conhecida como Consolidação Piragibe.

\footnotetext{
${ }^{23}$ Art.179. Reluzir á escravidão a pessoa livre, que se achar em posse da sua liberdade. Penas - de prisão por tres a nove annos, e de multa correspondente á terça parte do tempo; nunca porém o tempo de prisão será menor, que o do captiveiro injusto, e mais uma terça parte.

${ }^{24}$ BITTENCOURT. Cezar Roberto. Manual de Direito Penal: parte especial. Volume2. $2^{\mathrm{a}}$ Edição. São Paulo. Saraiva. 2002, pág 454.

${ }^{25}$ Código Penal dos Estados Unidos do Brasil, Decreto 847, de 11 de outubro de 1890
} 
O Código Penal de 1940 trouxe, em seu capítulo "Contra a liberdade individual", no artigo 149, o tipo penal de redução à condição análoga à de escravo, também chamado de plágio $^{26}$ em questão com a seguinte redação:

"Art.149. Reduzir alguém a condição análoga à de escravo:

Pena: reclusão, de dois a oito anos"

No ano de 2003, por meio da lei 10.803, devido às mudanças sociais ocorridas no Brasil desde a década de 50, o legislador encontrou a necessidade de alterar o tipo penal do crime de redução a condição análoga à de escravo, acrescentando novos núcleos, de modo a abranger novas condutas, ganhando a seguinte redação:

Art.149. Reduzir alguém a condição análoga à de escravo, quer submentendo-o a trabalhos forçados ou a jornada exaustiva, quer sujeitando-o a condições degradantes de trabalho, quer restringindo, por qualquer meio, sua locomoção em razão de dívida contraída com o empregador ou preposto:

Pena: reclusão, de dois a oito anos, e multa, além da pena correspondente à violência.

$\S 1^{\circ}$ Nas mesmas penas incorre quem:

I - cerceia o uso de qualquer meio de transporte por parte do trabalhador, com o fim de retê-lo no local de trabalho;

II - mantém vigilância ostensiva no local de trabalho ou se apodera de documentos ou objetos pessoais do trabalhador, com o fim de retê-lo no local de trabalho;

$\S 2^{\circ}$ A pena é aumentada de metade, se o crime é cometido:

I - contra criança ou adolescente;

II - por motivo de preconceito de raça, cor etnia, religião ou origem.

\footnotetext{
26 "Na Idade Média, era chamado plagium não só o furto de servos, como o rapto de homens ou crianças non libidins causa. Posteriormente, já extinta a escravidão de direito, o nome plagium ainda continuou a ser usado para designar a escravização de fato." HUNGRIA, Nelson; FRAGOSO, Heleno. Comentários ao Código Penal VI: arts. 137 ao 154. $5^{\text {a }}$ Edição. Rio de Janeiro. Forense. 1982. pág 198
} 
Cumpre salientar que o Brasil é signatário do Pacto de São José de Costa Rica (Convenção Americana de Direitos Humanos) de 1969 que dispõe no seguinte sentido:

Artigo 6 - Proibição da escravidão e da servidão 1. Ninguém poderá ser submetido à escravidão ou servidão e tanto estas como o tráfico de escravos e o tráfico de mulheres são proibidos em todas as suas formas. 2. Ninguém deve ser constrangido a executar trabalho forçado ou obrigatório. Nos países em que se prescreve, para certos delitos, pena privativa de liberdade acompanhada de trabalhos forçados, esta disposição não pode ser interpretada no sentido de proibir o cumprimento da dita pena, imposta por um juiz ou tribunal competente. $\mathrm{O}$ trabalho forçado não deve afetar a dignidade, nem a capacidade física e intelectual do recluso.

3. Não constituem trabalhos forçados ou obrigatórios para os efeitos deste artigo: a) os trabalhos ou serviços normalmente exigidos de pessoa reclusa em cumprimento de sentença ou resolução formal expedida pela autoridade judiciária competente. Tais trabalhos ou serviços devem ser executados sob a vigilância e controle das autoridades públicas, e os indivíduos que os executarem não devem ser postos à disposição de particulares, companhias ou pessoas jurídicas de caráter privado;

b) serviço militar e, nos países em que se admite a isenção por motivo de consciência, qualquer serviço nacional que a lei estabelecer em lugar daquele;

c) o serviço exigido em casos de perigo ou de calamidade que ameacem a existência ou o bem-estar da comunidade;

d) o trabalho ou serviço que faça parte das obrigações cívicas normais.

Como Tratado Internacional assinado e ratificado no Brasil, de acordo com o artigo $5^{\circ}$ da Constituição Federal de $1988^{27}$ e com a jurisprudência do Supremo Tribunal Federal ${ }^{28}$, deve o Tratado ter força de lei supra legal, devendo ser obedecida internamente.

\footnotetext{
${ }^{27}$ Art. $5^{\circ}$ Todos são iguais perante a lei, sem distinção de qualquer natureza, garantindo-se aos brasileiros e aos estrangeiros residentes no País a inviolabilidade do direito à vida, à liberdade, à igualdade, à segurança e à propriedade, nos termos seguintes:

(...)

$\S 1^{\circ}$ - As normas definidoras dos direitos e garantias fundamentais têm aplicação imediata.

$\S 2^{\circ}$ - Os direitos e garantias expressos nesta Constituição não excluem outros decorrentes do regime e dos princípios por ela adotados, ou dos tratados internacionais em que a República Federativa do Brasil seja parte.

$\S 3^{\circ}$ Os tratados e convenções internacionais sobre direitos humanos que forem aprovados, em cada Casa do Congresso Nacional, em dois turnos, por três quintos dos votos dos respectivos membros, serão equivalentes às emendas constitucionais.

$\S 4^{\circ} \mathrm{O}$ Brasil se submete à jurisdição de Tribunal Penal Internacional a cuja criação tenha manifestado adesão.

28 "Portanto, diante do inequívoco caráter especial dos tratados internacionais que cuidam da proteção dos direitos humanos, não é difícil entender que a sua internalização no ordenamento
} 


\section{2 - $O$ tipo penal do artigo 149 e sua interpretação antes da alteração realizada pela Lei 10.803 de Dezembro de 2003}

Antes da alteração realizada pela Lei 10.803/2003, o tipo penal contido no artigo 149 do Código Penal era muito simples, traduzia uma conduta simples que era a de reduzir alguém a condição análoga de escravo, onde o objeto da tutela jurídica era a liberdade individual, no particular aspecto do status libertatis, para que não se submeta a pessoa humana à servidão e ao poder de fato de outra pessoa. ${ }^{29}$

Nesse sentido, podemos verificar que era pacífico na doutrina que o bem tutelado pelo referido tipo penal é a liberdade. ${ }^{30}$ Para que se restasse configurado o delito, era necessário que houvesse de fato uma restrição de liberdade e submissão entre o agente passivo e ativo. Nesse sentido, podemos observar o que diz o Mestre Heleno Fragoso:

jurídico, por meio do procedimento de ratificação previsto na Constituição, tem o condão de paralisar a eficácia jurídica de toda e qualquer disciplina normativa infraconstitucional com ela conflitante. Nesse sentido, é possível concluir que, diante da supremacia da Constituição sobre os atos normativos internacionais, a previsão constitucional da prisão civil do depositário infiel (art. $5^{\circ}$, inciso LXVII) não foi revogada pela ratificação do Pacto Internacional dos Direitos Civis e Políticos (art. 11) e da Convenção Americana sobre Direitos Humanos - Pacto de San José da Costa Rica (art. $\left.7^{\circ}, 7\right)$, mas deixou de ter aplicabilidade diante do efeito paralisante desses tratados em relação à legislação infraconstitucional que disciplina a matéria, incluídos o art. 1.287 do Código Civil de 1916 e o Decreto-Lei n ${ }^{\circ} 911$, de $1^{\circ}$ de outubro de 1969. Tendo em vista o caráter supralegal desses diplomas normativos internacionais, a legislação infraconstitucional posterior que com eles seja conflitante também tem sua eficácia paralisada. É o que ocorre, por exemplo, com o art. 652 do Novo Código Civil (Lei n 10.406/2002), que reproduz disposição idêntica ao art. 1.287 do Código Civil de 1916" - Supremo Tribunal Federal, Recurso Extraordinário, nº 466.343, rel. Min. Cesar Peluso.

${ }^{29}$ FRAGOSO, Heleno C. Lições de Direito Penal. Volume II. 10a Edição. Editora Forense. Pág 265.

30 "Competência: o crime, na essência, tem por objeto jurídico a proteção à liberdade de ir, vir e querer da pessoa humana.” NUCCI, Guilherme. Código Penal Comentado. 9a Edição. São Paulo: Revista dos Tribunais. 2008. pág 694. 
"Entre o agente e o sujeito passivo se estabelece uma relação tal, que o primeiro se apodera totalmente da liberdade pessoal do segundo, ficando este reduzido, de fato, a um estado de passividade idêntica à do antigo cativeiro." 31

Nelson Hungria também possui posicionamento no mesmo sentido, em sua obra Comentários ao Código Penal:

"O crime de que ora se trata (art. 149) é a completa sujeição de uma pessoa ao poder de outra. Protege a lei penal, aqui, o status libertatis, ou seja, a liberdade no conjunto de suas manifestações. Refere-se o texto legal à "condição análoga à de escravo", deixando bem claro que não se cogita de redução à escravidão, que é um conceito jurídico, isto é pressupondo a possibilidade legal do domínio de um homem sobre o outro. $O$ status libertatis, como estado de direito, permanece inalterado, mas, de fato, é suprimido. "32

Bento de Faria também compactua com a doutrina majoritária à época, dispondo que:

"II - Somente se justifica a previsão dessa condição (escravidão) como estado de fato análogo, que se verifica quando o agente sujeita outra pessoa ao seu próprio poder, mantendo-a em estado de sujeição absoluta, com a supressão total de sua vontade de querer e entender livremente." (grifo nosso) ${ }^{33}$

O juiz do trabalho Guilherme Guimarães Feliciano também expõe essa visão em seu artigo, dizendo que:

“(...) para alguns, apenas se consumava o crime quando o sujeito ativo anulava totalmente a liberdade humana da vítima reduzindo-a à condição de coisa, " como o escravo da velha Roma”, e exercendo sobre ela completo senhorio e domínio.”34

Podemos então concluir que, para restar configurado o crime de redução a condição análoga à de escravo antes de 2003, era necessária total

31 FRAGOSO, H.C. Lições de Direito Penal. Parte Especial I, página 160.

${ }^{32}$ HUNGRIA, Nélson; FRAGOSO, Heleno. Comentários ao Código Penal, volume VI: arts 137 ao 157. 5 Edição. Rio de Janeiro. Editora Forense, 1982. pág. 199.

33 DE FARIA, Bento. Código Penal Comentado, Volume IV, Distribuidora Record Editora, Rio de Janeiro, 1959. pág 267

${ }^{34}$ Guilherme Guimarães Feliciano. Redução à Condição Análoga à de Escravo, na Redação da Lei $\mathrm{n}^{\circ} 10.803 / 03$. Artigo encontrado na Biblioteca do Tribunal de Justiça do Estado do Rio de Janeiro.

RDPPP n²5 - abril/maio/2004 
submissão do sujeito passivo ao sujeito ativo, sendo imperativo que o primeiro tenha a sua liberdade cerceada pelo segundo. ${ }^{35}$

\subsection{1 - O tipo penal aberto de 1950 e o tipo penal criado pela nova lei.}

O texto original do tipo penal do artigo 149, elaborada em 1950, era um tipo penal aberto, ou seja, não possuía uma descrição completa da conduta proibida pela lei penal.

Nesse sentido, faz-se necessária a complementação do tipo penal pelo intérprete, vez que, nos tipos penais abertos, pela sua simples leitura, não há a possibilidade de aferirmos, sem o necessário complemento, pela subsunção da conduta do agente. ${ }^{36}$

Um dos exemplos mais citados na doutrina é o do artigo 134 do Código Penal, que possui o texto: "expor ou abandonar recém-nascido, para ocultar desonra própria.”. Sobre o artigo, Nucci se posiciona:

"O tipo exige que se faça um juízo valorativo acerca do termo desonra, que não é meramente descritivo, mas normativo, além de conter o elemento especial referente à vontade do agente, que é para ocultar desonra própria,37

Podemos verificar que, antes da mudança realizada pela lei 10.803 de 2013, o tipo penal do artigo 149 era um tipo penal aberto, que dependia da interpretação do magistrado para a sua aplicação. Após a mudança legislativa, o legislador criou uma série de novos tipos, visando determinar todas as condutas que deveriam ser incriminadas, vez que, o pensamento

\footnotetext{
35 “Que se deve entender por - condição análoga à de escravo?

É sujeitar o direito individual da liberdade ao domínio absoluto de outrem. (o agente)” Idem. Pág 268

${ }^{36}$ GREGO. Rogério. Curso de Direito Penal. Parte Geral. 12a Edição. Editora Impetus. 2010. Rio de Janeiro. Pág 162 e 163.

${ }^{37}$ NUCCI. Guilherme de Souza. Manual de Direito Penal - Parte Geral. $7^{a}$ Edição. São Paulo. Editora Revista dos Tribunais. 2011. pág 199
} 
predominante antes da vigência da lei era de que o sujeito passivo tinha que ter seu direito à liberdade de ir e vir cerceado para que o crime restasse configurado. $^{38}$

Podemos observar a linha de raciocínio adotada pelo Ilustre doutrinador Celso Delmanto:

"Delito não configurado: o procedimento de fazendeiro que impede a mudança de colonos, de sua propriedade, por estarem em débito com a mesma, é censurável, mas não constitui o delito do art.149; este crime importa na completa sujeicão da pessoa ao poder de outrem, não se configurando quando a vítima tinha liberdade na sua locomocão (TJSP,RT282/150). Para que se configure o delito, necessário se faz a segura verificacão de total sujeicão, de supressão do estado de liberdade, sujeitando a vítima, moral e fisicamente, ao poder do dominador; não é qualquer constrangimento gerado por irregularidades nas relações laborativas suficiente para determinar a incidência do art. 149 (TJRS, RT 722/515). Inocorre o crime do artigo 149 se as supostas vítimas vivem na fazenda do réu, sem receber salário, mas recebem tratamento razoável. (TJPR, PJ 47/294)"39 (grifo nosso)

Com a alteração da lei 10.803/2003, o tipo penal do artigo 149 deixou de ser um tipo penal aberto e passou a ser tipo penal fechado, caracterizado por elementos descritivos, que não dependem do trabalho de complementação do intérprete, para que sejam compreendidos. ${ }^{40}$

Essa mudança ocorreu porque o legislador se deu ao trabalho de tipificar novas condutas, de maneira a restringir a aplicação do direito penal

\footnotetext{
38 "O bem jurídico protegido, neste tipo penal, é a liberdade individual, isto é o status libertatis".

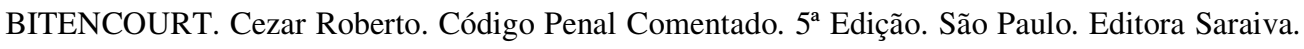
2009. pág. 492

39 DELMANTO. Celso. Código Penal comentado: acompanhado de comentários, jurisprudência, súmulas em matéria penal e legislação complementar. $8^{a}$ Edição. São Paulo. Saraiva. 2010. pág. 534

${ }^{40}$ NUCCI. Guilherme de Souza. Manual de Direito Penal - Parte Geral. $7^{\text {a }}$ Edição. São Paulo. Editora Revista dos Tribunais. 2011. pág 199
} 
às hipóteses por ele enumeradas, sejam elas: submeter a trabalhos forçados ou jornada exaustiva, sujeitar a condições degradantes de trabalho, restringir, por qualquer meio, sua locomoção em razão de dívida, cercear o uso de qualquer meio de transporte, manter vigilância ostensiva ou apoderar-se de documentos os objetos pessoais do sujeito passivo com objetivo de mantê-lo no local de trabalho. ${ }^{41}$

\section{3-As mudanças trazidas pela Lei 10.803 de dezembro de 2003}

O tipo penal do artigo 149 antes da lei 10.803 de 2003 era um tipo penal aberto, fato esse que trazia certa dificuldade ao julgador de definir o quando estaria o sujeito ativo incidindo na conduta criminosa.

A lei 10.803 foi criada com o objetivo de ampliar o rol de condutas que caracterizam o crime de redução a condição análoga à de escravo, tendo em vista que havia grande pressão das classes trabalhadoras nacionais e de órgãos internacionais para a plena criminalização da escravidão no Brasil.

Podemos verificar o impacto da mudança do tipo do artigo 149 do Código Penal por meio da visão de Ney Moura Teles:

\footnotetext{
${ }^{41}$ Artigo 149, Código Penal -Reduzir alguém a condição análoga à de escravo, quer submentendoo a trabalhos forçados ou a jornada exaustiva, quer sujeitando-o a condições degradantes de trabalho, quer restringindo, por qualquer meio, sua locomoção em razão de dívida contraída com o empregador ou preposto:

Pena: reclusão, de dois a oito anos, e multa, além da pena correspondente à violência. $\S 1^{\circ}$ Nas mesmas penas incorre quem:

I - cerceia o uso de qualquer meio de transporte por parte do trabalhador, com o fim de retê-lo no local de trabalho;

II - mantém vigilância ostensiva no local de trabalho ou se apodera de documentos ou objetos pessoais do trabalhador, com o fim de retê-lo no local de trabalho;

$\$ 2^{\circ}$ A pena é aumentada de metade, se o crime é cometido:

I - contra criança ou adolescente;

II - por motivo de preconceito de raça, cor etnia, religião ou origem.
} 
"A redação original do art. 149 levava a enormes dificuldades para a verificação da tipicidade do fato, exigindo-se, então, que o agente realizasse condutas que, em seu conjunto, impusessem à vítima a modificação de seu estado de liberdade, alterando seu estado de liberdade natural de ser humano livre, de modo que se assemelhasse ao estado de fato de um verdadeiro escravo, sem o poder de decidir sobre seus destinos. (...) Com a nova redação do art. 149, dada pela Lei $\mathrm{n}^{\circ} 10.803$, de 11 de dezembro de 2003, as dificuldades ficam minimizadas, senão que desaparecem." ${ }^{42}$

Sobre a mudança trazida pela lei 10.803/2003, podemos observar que a doutrina trabalhista alterou sua linha entendimento, ressaltando que, a restrição de liberdade não é fundamental para a caracterização do crime de redução à condição análoga a de escravo:

"Na atual definição que deve ser emprestada ao trabalho em que há a redução do homem à condição análoga à de escravo deve forçosamente ser reconhecido que não é mais a liberdade o fundamento maior que é violado, mas sim outro, mais amplo, e que repele as duas espécies: o trabalho forçado e o trabalho em condições degradantes." 43

A nova redação dada pela lei 10.803/2003 acrescentou diversas condutas que devem ser interpretadas como um tratamento análogo ao tratamento que era dado aos escravos, ou seja, que ferem a dignidade do trabalhador, de modo à reduzi-lo à situação de fato de escravo.

Dentre essas condutas, podemos destacar o cerceamento do uso de qualquer meio de transporte com o fim de retê-lo no local de trabalho, a vigilância ostensiva no local de trabalho ou apoderamento de objetos e/ou documentos pessoais do trabalhador e a submissão ao trabalho em condições degradantes.

\footnotetext{
${ }^{42}$ Ney Moura Teles, Direito Penal: parte especial, São Paulo, Atlas, 2004, v. II, p.302

43 BRITO FILHO. José Cláudio Monteiro de. Trabalho com redução do homem à condição análoga à de escravo e dignidade da pessoa humana. Encontrado no link: http://pgt.mpt.gov.br/publicacoes/escravo/dignidade-trabalhoescravo.pdf
} 
Importante ressaltar aqui que a nova lei não especificou o que devese entender pela expressão "condições degradantes", devendo o julgador ponderar, de acordo com os elementos colhidos durante a instrução processual, se a situação de fato enquadra-se na descrição do tipo ou deve ser enquadrada em outros tipos penais ou até mesmo em sanções trabalhistas.

\subsection{1-Da mudança de competência para julgar a conduta trazida no artigo 149 do Código Penal.}

Antes da mudança legislativa, o artigo tinha como bem jurídico a liberdade individual, após a lei 10.803, o bem jurídico tutelado passou a ser também o da organização das relações de trabalho.

Antes de 2003, não havia dúvida da competência estadual para julgar qualquer pessoa que incidisse na conduta tipificada pelo artigo 149, vez que, o bem jurídico tutelado (liberdade) não se enquadrava em nenhuma das hipóteses descritas no artigo 109 da Constituição da República, que determina a competência da justiça federal.

Após a mudança, porém, o bem jurídico foi alterado, passando a se enquadrar na hipótese do inciso VI, do artigo 109 da Constituição: "as ações oriundas da relação de trabalho." 44

\footnotetext{
${ }^{44}$ Art. 109. Constituição da República - Aos juízes federais compete processar e julgar:

I - as causas em que a União, entidade autárquica ou empresa pública federal forem interessadas na condição de autoras, rés, assistentes ou oponentes, exceto as de falência, as de acidentes de trabalho e as sujeitas à Justiça Eleitoral e à Justiça do Trabalho;

II - as causas entre Estado estrangeiro ou organismo internacional e Município ou pessoa domiciliada ou residente no País;

III - as causas fundadas em tratado ou contrato da União com Estado estrangeiro ou organismo internacional;
} 
Com isso, a competência para julgar o crime do artigo 149, que era da Justiça Comum, passou a ser da Justiça Federal, caracterizando assim uma alteração de competência.

IV - os crimes políticos e as infrações penais praticadas em detrimento de bens, serviços ou interesse da União ou de suas entidades autárquicas ou empresas públicas, excluídas as contravenções e ressalvada a competência da Justiça Militar e da Justiça Eleitoral;

V - os crimes previstos em tratado ou convenção internacional, quando, iniciada a execução no País, o resultado tenha ou devesse ter ocorrido no estrangeiro, ou reciprocamente;

$\mathrm{V}$-A as causas relativas a direitos humanos a que se refere o $\S 5^{\circ}$ deste artigo;

VI - os crimes contra a organização do trabalho e, nos casos determinados por lei, contra o sistema financeiro e a ordem econômico-financeira;

VII - os "habeas-corpus", em matéria criminal de sua competência ou quando o constrangimento provier de autoridade cujos atos não estejam diretamente sujeitos a outra jurisdição;

VIII - os mandados de segurança e os "habeas-data" contra ato de autoridade federal, excetuados os casos de competência dos tribunais federais;

IX - os crimes cometidos a bordo de navios ou aeronaves, ressalvada a competência da Justiça Militar;

$\mathrm{X}$ - os crimes de ingresso ou permanência irregular de estrangeiro, a execução de carta rogatória, após o "exequatur", e de sentença estrangeira, após a homologação, as causas referentes à nacionalidade, inclusive a respectiva opção, e à naturalização;

$\mathrm{XI}$ - a disputa sobre direitos indígenas.

$\S 1^{\circ}$ - As causas em que a União for autora serão aforadas na seção judiciária onde tiver domicílio a outra parte.

$\S 2^{\circ}$ - As causas intentadas contra a União poderão ser aforadas na seção judiciária em que for domiciliado o autor, naquela onde houver ocorrido o ato ou fato que deu origem à demanda ou onde esteja situada a coisa, ou, ainda, no Distrito Federal.

$\S 3^{\circ}$ - Serão processadas e julgadas na justiça estadual, no foro do domicílio dos segurados ou beneficiários, as causas em que forem parte instituição de previdência social e segurado, sempre que a comarca não seja sede de vara do juízo federal, e, se verificada essa condição, a lei poderá permitir que outras causas sejam também processadas e julgadas pela justiça estadual.

$\S 4^{\circ}$ - Na hipótese do parágrafo anterior, o recurso cabível será sempre para o Tribunal Regional Federal na área de jurisdição do juiz de primeiro grau.

$\S 5^{\circ}$ Nas hipóteses de grave violação de direitos humanos, o Procurador-Geral da República, com a finalidade de assegurar o cumprimento de obrigações decorrentes de tratados internacionais de direitos humanos dos quais o Brasil seja parte, poderá suscitar, perante o Superior Tribunal de Justiça, em qualquer fase do inquérito ou processo, incidente de deslocamento de competência para a Justiça Federal. 
Nesse sentido, podemos observar os seguintes julgados:

"CONFLITO DE COMPETÊNCIA. PROCESSUAL PENAL. CRIME DE REDUÇÃO A CONDIÇÃO ANÁLOGA À DE ESCRAVO. ART. 149 DO CÓDIGO PENAL. RESTRIÇÃO À LIBERDADE DO TRABALHADOR NÃO É CONDIÇÃO ÚNICA DE SUBSUNÇÃO TÍPICA. TRATAMENTO SUBUMANO AO TRABALHADOR. COMPETÊNCIA DA JUSTICA FEDERAL.

1. Para configurar o delito do art. 149 do Código Penal não é imprescindível a restrição à liberdade de locomoção dos trabalhadores, a tanto também se admitindo a sujeição a condições degradantes, subumanas.

2. Tendo a denúncia imputado a submissão dos empregados a condições degradantes de trabalho (falta de garantias mínimas de saúde, segurança, higiene e alimentação), tem-se acusação por crime de redução a condição análoga à de escravo, de competência da jurisdição federal." ${ }^{45}$ (grifo nosso)

"CONFLITO DE COMPETÊNCIA. CRIME DE REDUÇÃO A CONDIÇÃO ANÁLOGA À DE ESCRAVO. COMPETÊNCIA DA JUSTIÇA FEDERAL. PRECEDENTES DESTA CORTE E DO SUPREMO TRIBUNAL FEDERAL. COMPETÊNCIA DA JUSTIÇA FEDERAL.

- Nos termos da jurisprudência firmada nesta Corte e no Supremo Tribunal Federal, compete à Justiça Federal processar e julgar o crime de redução a condição análoga à de escravo, pois a conduta ilícita de suprimir dos trabalhadores direitos trabalhistas constitucionalmente conferidos viola o princípio da dignidade da pessoa humana, bem como todo o sistema de organização do trabalho e as instituiç̃oes e órgãos que o protegem.

Conflito conhecido para declarar competente o Juízo Federal da $11^{\text {a } V a r a ~ d a ~}$ Seção Judiciária do Estado de Goiás, ora suscitado.” ${ }^{46}$ (grifo nosso)

EMENTA:DIREITO PENAL E PROCESSUAL PENAL. ART. 149 DO CÓDIGO PENAL REDUÇÃO Á CONDIÇÃO ANÁLOGA À DE ESCRAVO. TRABALHO ESCRAVO. DIGNIDADE DA PESSOA HUMANA. DIREITOS FUNDAMENTAIS. CRIME CONTRA A COLETIVIDADE DOS TRABALHADORES. ART. 109, VI DA CONSTITUIÇÃO FEDERAL. COMPETÊNCIA. JUSTIÇA FEDERAL. RECURSO EXTRAORDINÁRIO PROVIDO. A Constituição de 1988 traz um robusto conjunto normativo que visa à proteção e efetivação dos direitos fundamentais do ser humano. A existência de

\footnotetext{
${ }^{45}$ Superior Tribunal de Justiça. Conflito de competência nº127937/GO. Relator: Ministro Nefi Cordeiro. Data de Julgamento: 28/05/2014

${ }^{46}$ Superior Tribunal de Justiça. Conflito de competência $n^{\circ} 132884 / G O$. Relator: Ministro Marilza Maynard.Data de julgamento: 28/05/2014.
} 
trabalhadores a laborar sob escolta, alguns acorrentados, em situação de total violação da liberdade e da autodeterminação de cada um, configura crime contra a organização do trabalho. Quaisquer condutas que possam ser tidas como violadoras não somente do sistema de órgãos e instituições com atribuições para proteger os direitos e deveres dos trabalhadores, mas também dos próprios trabalhadores, atingindo-os em esferas que lhes são mais caras, em que a Constituição lhes confere proteção máxima, são enquadráveis na categoria dos crimes contra a organização do trabalho, se praticadas no contexto das relações de trabalho. Nesses casos, a prática do crime prevista no art. 149 do Código Penal(Reducão à condicão análoga a de escravo) se caracteriza como crime contra a organização do trabalho, de modo a atrair a competência da Justiça federal (art. 109, VI da Constituicão) para processá-lo e julgá-lo. Recurso extraordinário conhecido e provido. (grifo nosso $)^{47}$

Encontramos ainda respaldo nos ensinamentos do Mestre César Roberto Bittencourt que faz uma coletânea de julgados sobre o assunto:

“ "O acórdão recorrido diverge do atual posicionamento do Superior Tribunal de Justiça que se firmou no sentido de que o crime de redução a condição análoga à de escravo, por se enquadrar na categoria de delitos contra a organização do trabalho é de livre competência da Justiça Federal, nos termos do artigo 109, inciso VI, da Constituição Federal. (STJ, REsp 909.340/PA, Rel. Min. Laurita Vaz, j. 25-9-2007)

"Na esteira do atual entendimento do Supremo Tribunal Federal e desta Corte, o crime de redução a condição análoga à de escravo, ainda que praticado contra determinados grupos de trabalhadores, por se enquadrar na categoria de delitos contra a organização do trabalho, é de competência da Justiça Federal, nos termos do art. 109, inciso VI, da Constituição Federal. (STJ, conflito de competência 62.156/MG, Rel. Min. Laurita Vaz, j. 27-6-2007)” ${ }^{48}$

Assim, podemos verificar a mudança no tipo penal do artigo 149, trazida pela lei 10.803 de 2003, além de adicionar núcleos ao tipo penal, alterou a competência para julgamento do crime de redução à condição análoga a de escravo.

\footnotetext{
${ }^{47}$ Supremo Tribunal Federal. RExt no 398041 / PA - PARÁ. Ministro Relator: Joaquim Barbosa. Data do julgamento: 30/06/2011.

${ }^{48}$ BITTENCOURT. César Roberto. Código Penal Comentado. $5^{a}$ Edição. Editora Saraiva. Saraiva 2009.pág.497
} 


\section{Capítulo 3 - A aplicação do princípio da Legalidade em casos anteriores às mudanças da Lei - casos concretos.}

É pacífico na doutrina e na jurisprudência atual que, se, hoje em dia, o sujeito de alguma forma submete o sujeito passivo à condições degradantes de trabalho ${ }^{49}$ que essa conduta estaria enquadrada no tipo penal do artigo 149 do Código Penal, mesmo que, essa conduta não resulte na privação de liberdade do sujeito passivo ou submissão total do mesmo ao sujeito ativo.

Nesse sentido, podemos observar os seguintes posicionamentos jurisprudenciais:

"EMENTA PENAL. REDUÇÃO A CONDIÇÃO ANÁLOGA A DE ESCRAVO. ESCRAVIDÃO MODERNA. DESNECESSIDADE DE COACÃO DIRETA CONTRA A LIBERDADE DE IR E VIR. DENÚNCIA RECEBIDA. Para configuração do crime do art. 149 do Código Penal, não é necessário que se prove a coação física da liberdade de ir e vir ou mesmo o cerceamento da liberdade de locomoção, bastando a submissão da vítima "a trabalhos forçados ou a jornada exaustiva" ou "a condições degradantes de trabalho", condutas alternativas previstas no tipo penal. A "escravidão moderna" é mais sutil do que a do século XIX e o cerceamento da liberdade pode decorrer de diversos constrangimentos econômicos e não necessariamente físicos. Priva-se alguém de sua liberdade e de sua dignidade tratando-o como coisa e não como pessoa humana, o que pode ser feito não só mediante coação, mas também pela violação intensa e persistente de seus direitos básicos, inclusive do direito ao trabalho digno. A violação do direito ao trabalho digno impacta a capacidade da vítima de realizar escolhas segundo a sua livre determinação. Isso também significa "reduzir alguém a condição análoga à de escravo". Não é qualquer violação dos direitos trabalhistas que configura trabalho escravo. Se a violacão aos direitos do trabalho é intensa e persistente, se atinge níveis gritantes e se os trabalhadores são submetidos a trabalhos forcados, jornadas exaustivas ou a condicões degradantes de trabalho, é possível, em tese, o enquadramento no crime do art. 149 do Código Penal, pois os trabalhadores estão recebendo o tratamento análogo

49 Fala-se aqui "condições degradantes de trabalho" de maneira exemplificativa, podendo-se substituir essa expressão por qualquer outra nova conduta incluída no tipo penal do artigo 149 pela Lei $10803 / 2003$. 
ao de escravos, sendo privados de sua liberdade e de sua dignidade. Denúncia recebida pela presença dos requisitos legais." ${ }^{50}$ (grifo nosso)

"PENAL. PROCESSUAL PENAL. DENÚNCIA. CRIMES DE REDUÇÃO A CONDIÇÃO ANÁLOGA À DE ESCRAVO E DE ALICIAMENTO DE TRABALHADORES. DESNECESSIDADE DE VIOLÊNCIA FÍSICA PARA A OCORRÊNCIA DO DELITO. PARA A CARACTERIZACÃO DO DELITO BASTA A REITERADA OFENSA AOS DIREITOS FUNDAMENTAIS DO TRABALHADOR, VULNERANDO SUA DIGNIDADE COMO SER HUMANO. PRESCRIÇÃO QUANTO AO DELITO DE FRUSTRAÇÃO DE DIREITO TRABALHISTA. DENUNCIADO COM IDADE SUPERIOR A SETENTA ANOS. RECEBIMENTO PARCIAL DA DENÚNCIA. I - A inicial acusatória contemplou a qualificação do acusado, a classificação do crime e o rol de testemunhas, apresentou informações essenciais sobre a prática das condutas, preenchendo os requisitos do art. 41 do CPP. II - Prescrição da pretensão punitiva estatal em relação ao delito de frustração de direito trabalhista, considerando a pena máxima cominada ao tipo penal (dois anos de detenção) e o fato de o prazo do art. 109, V, do Código Penal necessitar ser reduzido à metade (art. 115 do CP); a prescrição é, inclusive, anterior à remessa dos autos a esta Corte. III - A jurisprudência do Supremo Tribunal Federal entende ser desnecessário haver violência física para a configuração do delito de redução à condição análoga à de escravo. É preciso apenas a coisificação do trabalhador, com a reiterada ofensa adireitos fundamentais, vulnerando a sua dignidade como ser humano (Inq 3.412, Redatora p/ Acórdão: Min. Rosa Weber, Tribunal Pleno, DJe 12/11/2012). IV Presentes os indícios de materialidade e autoria, a denúncia foi parcialmente recebida para os crimes de redução a condição análoga à de escravo e de aliciamento de trabalhadores de um local para outro do território nacional, tipificados nos arts. 149 e 207, caput e $\S 1^{\circ}$, ambos do Código Penal." ${ }^{51}$ (grifo nosso)

“(...)O magistrado a quo, a despeito desse quadro, entendeu que não havia qualquer elemento que indicasse que o acusado reduzia seus trabalhadores a condições análogas a de escravo ressaltando que as relações de trabalho no Brasil, notadamente no campo, são historicamente precárias. Segundo o julgador, as constatações feitas pelos auditores fiscais do trabalho eram comuns no meio rural e representavam, na verdade, meras irregularidades administrativas, que foram sanadas pelo réu. Ainda de acordo com o magistrado, não ficou comprovado o cerceio à liberdade pessoal dos trabalhadores, elementos necessário à configuracão do crime do art. 149 do Código Penal, já que a Polícia Federal não encontrou ninguém portando arma de fogo, senão o preposto do réu, que admitiu que usava arma de brinquedo, para impor autoridade perante os trabalhadores.

Em que pese ao entendimento do julgador a quo, creio que, diante das graves constatações feitas pelos auditores fiscais do trabalho, é o caso de se prosseguir com a ação penal, ultimando-se a fase de instrução, já que os fatos narrados evidenciam claramente a prática do crime do art. 149 do Código Penal, que tipifica a conduta de "Reduzir alguém a condição análoga à de escravo, quer submetendo-o a trabalhos forçados ou a jornada exaustiva, quer sujeitando-o a

\footnotetext{
${ }^{50}$ Supremo Tribunal Federal. Inq 3412 / AL. Relator(a): Min. MARCO AURÉLIO. Julgamento: 29/03/2012

${ }^{51}$ Supremo Tribunal Federal. Inq 3564 / MG. Relator(a): Min. RICARDO LEWANDOWSKI.

Julgamento: 19/08/2014
} 
condições degradantes de trabalho, quer restringindo, por qualquer meio, sua locomoção em razão de dívida contraída com o empregador ou preposto."

Ora, como aceitar que trabalhadores sujeito a jornada de trabalho de mais de 10 (dez) horas (diárias), que laboram descalços, sem equipamentos de segurança, que são alimentados de forma precária e não dispõem de água própria para consumo, que dormem em alojamentos coletivos sujos, sobre fino colchão mantido no chão, intimidados por preposto armado, ainda que com arma brinquedo, não são submetidos a trabalho escravo? É forçoso reconhecer, portanto, que essas constatacões, incontroversas, ressalte-se, não constituem "meras irregularidades administrativas", mas são plenamente aptas a caracterizar o crime do art. 149 do Código Penal, sobretudo na modalidade de sujeição a condições degradantes de trabalho. (...) ${ }^{, 52}$ (grifo nosso)

O que é pouco analisado pelos doutrinadores e pelos Tribunais do país é o que ocorre quando a conduta do sujeito ativo se enquadraria às novas condutas introduzidas pela nova lei porém foi praticada antes da alteração da lei.

Como analisado até agora, podemos verificar que após a Lei 10.803/2003, o tipo do artigo 149 do Código Penal foi alterado e com isso, várias mudanças foram desencadeadas. Nesse capítulo, vamos analisar de que forma essas mudanças repercutem ou deveriam repercutir nos crimes praticados antes da lei, mas que ainda estão sendo julgados atualmente.

Podemos salientar duas hipóteses distintas no que tange à aplicação do princípio da legalidade: a primeira será quando o sujeito ativo de fato restringiu a liberdade de locomoção do sujeito passivo e, a segunda quando o sujeito ativo não restringiu a liberdade de locomoção do sujeito passivo porém o sujeitava à condições degradantes de trabalho.

\footnotetext{
52 Tribunal Regional Federal 2a Região. APELAÇÃO CRIMINAL 10319 2012.51.05.000548-0. Desembargador relator ANDRÉ FONTES. Data do julgamento: 06 de agosto de 2013.
} 


\section{1 - Quando o sujeito ativo restringiu a liberdade de locomoção do sujeito passivo}

Nessa hipótese, estaremos levando em consideração que o sujeito ativo, restringiu a liberdade do sujeito ativo, não permitindo que o mesmo circulasse livremente e o obrigando a trabalhar para ele de maneira a submetê-lo à uma condições vexatórias, de total submissão.

Nesse caso, mesmo a conduta do sujeito ativo sendo anterior à lei $10.803 / 2013$, o mesmo, ao ser julgado, restando comprovados todos os fatos imputados na denúncia, deve ser condenado pela prática do crime de redução à condição análoga a de escravo, vez que feriu o bem jurídico tutelado pelo artigo 149, à época da conduta praticada, qual seja, o "status libertatis".

\section{2 - Quando o sujeito ativo não restringiu a liberdade de locomoção do sujeito passivo, porém o último trabalhou em condições degradantes.}

Situação diversa é configurada nessa hipótese pois, aqui, a conduta praticada antes da mudança da lei não fere o tipo penal do artigo 149 à época de sua realização - ou seja, anteriores à 2003. Ou seja, nessa hipótese, o status libertatis não é lesado e nem suprimido, apenas as condições em que o sujeito passivo trabalha são "degradantes".

Nessa hipótese, não pode o sujeito ativo ser indiciado/processado/condenado pelo crime de redução a condição análoga à de escravo, mas sim, no máximo do artigo $132^{53}$ ou $136^{54}$ do Código

\footnotetext{
${ }^{53}$ Perigo para a vida ou saúde de outrem

Art. 132 - Expor a vida ou a saúde de outrem a perigo direto e iminente:

Pena - detenção, de 3 (três) meses a 1 (um) ano, se o fato não constitui crime mais grave.
} 
Penal. Isso porque, à época da conduta analisada, o sujeito ativo tinha como parâmetro o entendimento daquele momento específico, ou seja, de que para restar configurado o crime do artigo 149 do Código Penal seria necessária a restrição absoluta da liberdade do sujeito passivo.

Faz-se necessária uma diferenciação entre a redução à condição análoga à de escravo e condutas, para isso podemos nos valer das palavras de Maurício Pessoa Lima que diz:

"Com efeito, o labor degradante é aquele no qual o trabalhador é submetido a condições intoleráveis que atentem contra a sua higidez física e mental, agravadas pelo fato de não serem observadas as normas de higiene e segurança, nem serem dadas condições para uma alimentação razoável. Exemplo comum é o trabalho nas carvoarias do Maranhão, onde em muitos casos não há sequer o fornecimento dos equipamentos mínimos de proteção individual.

Já na super-exploração ocorre a supressão dosdireitos trabalhistas mais básicos. Como exemplo temos o não pagamento sequer do salário-mínimo, a exigência de jornadas excessivas ou altas cotas de produção, geralmente acompanhadas de fraudes. Já constatamos tal conduta na contratação de trabalhadores para o corte de cana-de-açúcar, com pagamento efetivado por produção, não se utilizando o empregador de balança para aferir a produção individual.

Não é raro encontrarmos todas estas irregularidades juntas, e diante de sua gravidade serem taxadas equivocadamente de trabalho escravo.

São condutas que devem ser reprimidas, mas que não configuram, por si sós, a condição análoga à de escravo. Podem, como veremos mais adiante, configurar outros crimes, como a "frustração de direito trabalhista mediante fraude" (artigo 203 do Código Penal), e também a "exposição da vida ou saúde de outrem a perigo direto e iminente" (artigo 132 do Código Penal)."

Podemos nos valer dos seguintes julgados que também fazem a diferenciação entre condições precárias de trabalho e a conduta de reduzir alguém à condição análoga a de escravo:

\footnotetext{
${ }^{54}$ Maus tratos

Art. 136 - Expor a perigo a vida ou a saúde de pessoa sob sua autoridade, guarda ou vigilância, para fim de educação, ensino, tratamento ou custódia, quer privando-a de alimentação ou cuidados indispensáveis, quer sujeitando-a a trabalho excessivo ou inadequado, quer abusando de meios de correção ou disciplina:

Pena - detenção, de 2 (dois) meses a 1 (um) ano, ou multa.

55 Maurício Pessoa Lima. O trabalho em condições análogas a de escravo no Brasil contemporâneo. Encontrado no site: www.oit.org.br
} 
PENAL. PROCESSUAL PENAL. FRUSTRAÇÃO DE DIREITO ASSEGURADO POR LEI TRABALHISTA. CP, ART. 203. EXTINÇÃO DA PUNIBILIDADE PELA PRESCRIÇÃO DA PENA EM CONCRETO. REDUÇÃO DE TRABALHADOR A CONDIÇÃO ANÁLOGA À DE ESCRAVO. CP, ART. 149. PROVA DA MATERIALIDADE. INEXISTÊNCIA. REFORMA DA SENTENÇA CONDENATÓRIA. CPP, ART. 386, INCISO III.

1. Quanto ao crime previsto no art. 203 do Código Penal (frustração de direito assegurado por lei trabalhista), os réus foram condenados a 1 (um) ano, 5 (cinco) meses e 15 (quinze) dias de detenção (fl. 726), caso em que a prescrição ocorre em 4 (quatro) anos (art. 109, V, do Código Penal). Considerando que entre a data do recebimento da denúncia (17/05/2007) e a data da publicação da sentença condenatória (16/01/2012) transcorreram mais de 4 (quatro) anos, encontra-se extinta a pretensão punitiva, pela prescrição da pena em concreto.

2. Para a configuração de redução de trabalhador a condição análoga à de escravo faz-se necessária a completa sujeição da pessoa que tenha relação de trabalho ao poder do sujeito ativo do crime, não bastando a submissão do trabalhador a condições precárias de acomodações. Tal situação é censurável, mas não configura o crime do art. $149, \S 2^{\circ}$, do Código Penal.

3. Declaração, de ofício, da extinção da punibilidade dos réus, pela pena em concreto, quanto ao crime do art. 203 do Código Penal, prejudicada, no ponto, a apelação.

4. Reforma da sentença condenatória que se impõe, para absolver os apelantes da prática do crime do art. $149, \S 2^{\circ}$, do Código Penal, com fundamento no art. 386, III, do Código de Processo Penal. ${ }^{56}$

O indiciamento/ condenação do sujeito passivo nessa hipótese pelo crime contido no artigo 149 do Código Penal é uma afronta aos princípios da taxatividade, ao da irretroatividade penal, vez que estaria o sujeito ativo sendo condenado por um fato que à época de sua conduta não era criminalmente puníveis.

É de extrema importância ressaltar que a conduta praticada pelo sujeito ativo é moralmente recriminável e que esta monografia não apóia a impunidade mas sim a defesa das garantias fundamentais para uma maior segurança jurídica.

\footnotetext{
56 Tribural Regional Federal $1^{\mathrm{a}}$ Região. Apelação Criminal $\mathrm{n}^{\mathrm{o}}$ 2007.36.00.008387-4. DESEMBARGADOR FEDERAL HILTON QUEIROZ. Data de julgamento:22 de julho de 2014.
} 
Ocorre que, os casos já como o da hipótese acima criada aconteceram até o ano de 2003, ano em que a lei foi promulgada e, a desclassificação do crime de condição análoga à de escravo para o crime de maus tratos seria de grande impacto, vez que essa desclassificação ocasionaria a prescrição da pretensão punitiva estatal. ${ }^{57}$

Sendo assim, devido à grande pressão política e clamor social do tema em tela, dificilmente o assunto é discutido e a acusação e condenação de pessoas que se enquadram na hipótese acima descrita permanece sendo possível e recorrente, como podemos analisar nos casos a seguir:

HABEAS CORPUS. RECEBIMENTO DE DENÚNCIA FUNDADA EM RELATÓRIO ADMINISTRATIVO PARA FINS PENAIS NÃO ASSINADO PELA AUTORIDADE COMPETENTE CRIME DE REDUÇÃO À CONDIÇÃO ANÁLOGA À DE ESCRAVO. COMPETÊNCIA DA JUSTIÇA FEDERAL. FRUSTRAÇÃO DE DIREITOS TRABALHISTASS.

${ }^{57} \mathrm{O}$ crime de condição análoga à de escravo prevê pena de reclusão de 2 a 8 anos. Logo, de acordo com o artigo 109 do Código Penal, para que a pretensão punitiva estatal reste prescrita, são necessários 12 anos.

O crime de maus tratos, por outro lado, possui pena prevista e dois meses a um ano e, de acordo com o artigo 109 do Código Penal, o mesmo prescreveria em 4 anos.

Art. 109. A prescrição, antes de transitar em julgado a sentença final, salvo o disposto no $§ 1$ o do art. 110 deste Código, regula-se pelo máximo da pena privativa de liberdade cominada ao crime, verificando-se: (Redação dada pela Lei no 12.234, de 2010).

I - em vinte anos, se o máximo da pena é superior a doze;

I - em vinte anos, se o máximo da pena é superior a doze;

II - em dezesseis anos, se o máximo da pena é superior a oito anos e não excede a doze;

II - em dezesseis anos, se o máximo da pena é superior a oito anos e não excede a doze;

III - em doze anos, se o máximo da pena é superior a quatro anos e não excede a oito;

III - em doze anos, se o máximo da pena é superior a quatro anos e não excede a oito;

IV - em oito anos, se o máximo da pena é superior a dois anos e não excede a quatro;

$\underline{V}$ - em quatro anos, se o máximo da pena é igual a um ano ou, sendo superior, não excede a dois;

VI - em dois anos, se o máximo da pena é inferior a um ano.

VI - em 3 (três) anos, se o máximo da pena é inferior a 1 (um) ano. (Redação dada pela Lei $n^{\circ}$ 12.234, de 2010).

VI - em 3 (três) anos, se o máximo da pena é inferior a 1 (um) ano. (Redação dada pela Lei $n^{\circ}$ 12.234, de 2010). 

$\begin{array}{lcccrr}\text { ALICIAMENTO } & \text { DE } & \text { TRABALHADORES. CRIMES } & \text { CONTRA A } \\ \text { ORGANIZAÇÃO } & \text { DO TRABALHO. INFRAÇÃO PENAL CONTRA } \\ \text { INTRESSE E CONTRA SERVIÇO DA UNIÃO. VIOLAÇÃO AO PRIMADO } \\ \text { DA GARANTIA DA DIGNIDADE DA PESSOA HUMANA. LESÃO À } \\ \text { PREVIDÊNCIA } & \text { SOCIAL. MANIFESTO INTERESSE DA UNIÃO. } \\ \text { COMPETENNCIA } & \text { DA JUSTIÇA A FEDERAL. RECEBIMENTO DA } \\ \text { DENÚNCIA. INDÍCIOS SUFICIENTES DE AUTORIA E MATERIALIDADE. }\end{array}$

1. O fato de o relatório administrativo não estar devidamente assinado constitui mero erro material, o que não prejudica o recebimento da denúncia, tendo em vista a extensa documentação apresentada em anexo, que se torna apta a satisfazer os requisitos dos artigos 41 e 43 do Código de Processo Penal.

2. Os crimes atribuídos aos pacientes envolvem valores que vão além da liberdade individual dos trabalhadores reduzidos à condição de escravos. Atingem interesse jurídico da União e atentam contra serviço privativo da União, deste modo, são de competência da Justiça Federal por expressa disposição do artigo 109, incisos IV e VI, da Constituição.

3. Tais infrações penais atentam contra o primado da garantia da dignidade da pessoa humana e da liberdade de trabalho, além de causar sérios prejuízos à Previdência Social, não havendo, portanto, que se afastar o interesse da União e a atribuição de competência à Justiça Federal, nos moldes do artigo 109 da Constituição Federal.

4. Não há afronta ao princípio da reserva legal porque o ilícito tipificado no artigo 149 do Código Penal é preexistente à Lei $\underline{10.803 / 2003 ~ o u ~ s e j a, ~ e s t a ~ l e i ~ n a ̃ o ~ c r i o u ~ n o v a ~ c o n d u t a ~ i n c r i m i n a d o r a, ~}$ mas apenas conferiu nova redação ao dispositivo que já repudiava criminalmente a prática de redução de trabalhadores a condição análoga à de escravos, sendo a figura típica contemporânea à data dos fatos.

5. O Termo de Ajustamento de Conduta não afasta os princípios da obrigatoriedade e da indisponibilidade da ação penal. Trata-se de compromisso assumido pelos pacientes de não mais celebrar contratos de trabalho em desconformidade com as leis trabalhistas, sob pena de aplicação de multa estabelecida no termo. Não impede a apuração da responsabilidade penal pela prática de condutas criminosas ocorridas antes ou após a assinatura do referido." (do opinativo ministerial).

6. Denúncia que, afeiçoada ao artigo 41 do Código de Processo Penal, não incorre nos motivos de rejeição elencados no seu artigo 43 , havendo justa causa para a persecução penal.

7. Pleito de uniformização de jurisprudência que se indefere, por inconciliável com a estreiteza da via processual do habeas corpus.

8. Constrangimento ilegal inocorrente. Ordem denegada.. ${ }^{58}$ (grifo nosso)

Situação semelhante à dos casos acima narrados é a que podemos

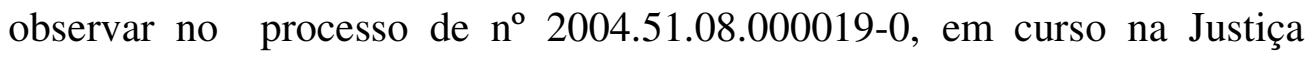

\footnotetext{
${ }^{58}$ Tribunal Reginal Federal $2^{\mathrm{a}}$ Região. Recurso em sentido Estrito.2006.50.01.005265-1. Relator: Desembargador Federal Sergio Feltrin Corrêa. Data de julgamento: 29 de novembro de 2006.
} 
Federal, que ainda não foi julgado e que os réus estão sendo acusados de reduzir os trabalhadores à condições análogas a de escravo.

Nesse caso concreto, é importante analisar que as condutas que dão ensejo às acusações - condições degradantes de trabalho narradas pelo Ministério Público são anteriores ao ano de 2003 - portanto anteriores à vigência da Lei 10.803/2003 e que, a locomoção dos trabalhadores em momento algum foi restringida, tendo em vista que no território de trabalho passavam linhas distintas de ônibus.

O caso ainda não fui julgado, porém se for analisado de acordo com o princípio da legalidade, merece os réus serem absolvidos, na linha da seguinte decisão do TRF $2^{\mathrm{a}}$ Região:

"Do pleito de condenação pelo crime de redução à condição análoga à de escravo (art. 149 do CP).

Argumenta a acusação que a situação em que os trabalhadores foram encontrados pelos auditores da Delegacia Regional do Trabalho do Rio de Janeiro era precária. Salienta ter sido relatado que os trabalhadores ficavam alojados em três imóveis, em péssimas condições de higiene e sujeitando-se a regime degradante de trabalho, pois além de receberem uma remuneração irrisória, aqueles que tentavam fugir do empregador eram perseguidos e ameaçados caso não pagassem as dívidas.

Sem razão o Ministério Público Federal.

Andou bem o magistrado sentenciante ao entender pela atipicidade das condutas dos apelados quanto ao crime em questão.

Com efeito, após aprofundada análise da prova carreada aos autos, especialmente a oitiva dos acusados e testemunhas, dentre estas o auditor fiscal do trabalho (Leonardo Alencar Osório Loppi - fls. 335/336) e a procuradora regional do trabalho (Regina Brutus - fls. 337/338), concluiu que (fls. 722/723):

“...no caso tratado nos autos, não houve submissão integral da vítima ao poder de disposição dos acusados. Consoante noticiam as testemunhas, não foi empregada violência ou ameaça, não lhes foram retidos salários (até porque trabalhavam de forma autônoma e pagavam as supostas dividas com o que auferiam, entregando, portanto, voluntariamente o produto da arrecadação laboral), não lhes restringiu comida e roupas e nunca impediu que os aliciados regressassem à Paraíba de modo voluntário.

As condições de acomodação eram evidentemente indignas e havia severas irregularidades nas contratações, mas estavam os trabalhadores possibilitados 
de circular livremente e até de buscar outro emprego ou mesmo o socorro das autoridades, se fosse o caso.

Ademais, as testemunhas foram uníssonas ao decantar que as jornadas eram livres e cumpridas ao alvedrio dos próprios 'vendedores', que inclusive optariam por estendê-las ao período noturno, que era o de maior movimento nas vendas e de mais significativa lucratividade, consoante historiou uma delas.

Ainda que tenha havido a efetiva contração de divida - fato este que está acima de questionamento, mesmo que negado pelos acusados -, fosse pelas antecipações creditadas ainda na origem, fosse pela entrega das redes e mantas para revenda, restrição à liberdade de locomocão, ainda que parcial, nunca houve.

Sem essa elementar do tipo, inviável o reconhecimento da figura criminosa de reducãa a condicão análoga à de escravo. .". "(grifo nosso $)^{59}$

59 Tribunal Regional Federal. 2 ${ }^{\mathrm{a}}$ Região. Ap.Criminal 2007.51.01.801556-0. Desembargador Relator: Desembargador Federal Messod Azulay Neto. Data do julgamento: 09 de julho de 2003. 


\section{Conclusão}

Após a análise nesse trabalho feita, podemos concluir que a Lei 10.803 de 2003 apresentou diversas mudanças no tipo penal do artigo 149. Dentre essas mudanças, verificamos o acréscimo de núcleos neste tipo penal.

O foco deste trabalho foi na análise de crimes cometidos antes da mudança da lei de 10.803 e que ainda estão sendo julgados e em como o princípio da legalidade deve ser aplicado de modo à absolver os acusados de reduzir à condição análoga de escravos quando os mesmos estiverem incidindo no crime somente pelos novos núcleos incluídos pela lei, vez que a mesma é posterior à conduta do agente.

A grande discussão encontrada para realizar o trabalho foi o fato de que muitos doutrinadores acreditam que a Lei 10.803/2003 veio apenas para exemplificar maneiras na qual o sujeito ativo possa submeter o sujeito passivo à escravidão.Apesar desses entendimentos, nos valendo da interpretação de doutrinadores anteriores à Lei, podemos ter uma clara visão de que antes da lei, a redução à condição análoga a de escravo consistia na restrição total da liberdade e submissão do sujeito passivo.

Portanto, a mudança da lei, representa uma inovação no sistema penal, vez que, para a configuração do crime de redução à condição análoga a de escravo atualmente, existem uma série de condutas novas que foram incriminadas, não só a restrição de liberdade e submissão similar à condição em que se vivia no cativeiro.

Essa inovação faz com que o Princípio da Legalidade se aplique sobre todos os casos em que o acusado esteja sendo processado pelo crime contido no tipo penal do artigo 149 do Código Penal e que sua conduta seja anterior ao ano de 2003. Isto é, na conjuntura acima apresentada, a única maneira de o acusado, tendo seus direitos fundamentais respeitados, ser 
condenado pela prática do crime de plágio $^{60}$, é de restar comprovado nos autos que o mesmo restringiu a liberdade de locomoção do sujeito passivo e o criou uma relação de submissão total entre eles.

60 "Na Idade Média, era chamado plagium não só o furto de servos, como o rapto de homens ou crianças non libidinis causa.

Posteriormente, já extinta a escravidão de direito, o nome plagium ainda continuou a ser usado para designar a escravização de fato.” HUNGRIA, Nélson. Comentários ao Código Penal, volume VI: arts.137 ao 154 por Nélson Hungria e Heleno Cláudio Fragoso. $5^{\text {a }}$ Edição, $1^{\text {a }}$ tiragem. Rio de Janeiro, Forense, 1982, pág 198. 


\section{Bibliografia}

BITENCOURT. Cezar Roberto. Código Penal Comentado. $5^{a}$ Edição. São Paulo. Editora Saraiva. 2009.

BITTENCOURT. Cezar Roberto. Manual de Direito Penal: parte especial. Volume2. 2a Edição. São Paulo. Saraiva. 2002

BITENCOURT, Cezar Roberto. Tratado de Direito Penal. Volume 2. 5a ed. São Paulo: Saraiva, 2006.

BONAVIDES, Paulo. Ciência política. São Paulo: Editora Malheiros, 1994.

BRUNO, Aníbal. Direito Penal v.1. Parte Geral. 3. ed. Rio de Janeiro: Forense, 1978.

DE FARIA, Bento. Código Penal Comentado, Volume IV, Distribuidora Record Editora, Rio de Janeiro, 1959

DELMANTO. Celso. Código Penal comentado: acompanhado de comentários, jurisprudência, súmulas em matéria penal e legislação complementar. 8 Edição. São Paulo. Saraiva. 2010.

FRAGOSO, Heleno C. Lições de Direito Penal. Volume II. $10^{\mathrm{a}}$ Edição. Editora Forense.

GRECO, Rogério. Curso de Direito Penal. $2^{\mathrm{a}}$ Edição. Rio de Janeiro. Editora Impetus. 2003.

GREGO. Rogério. Curso de Direito Penal. Parte Geral. 12a Edição. Editora Impetus. 2010. Rio de Janeiro. 
GRECO. Rogério. Curso de Direito Penal. 14 Edição. Rio de Janeiro. Editora Impetus. 2012.

HUNGRIA, Nélson; FRAGOSO, Heleno. Comentários ao Código Penal, volume VI: arts 137 ao 157. $5^{\text {a }}$ Edição. Rio de Janeiro. Editora Forense, 1982.

LENZA. Pedro. Direito Constitucional esquematizado. $16^{\mathrm{a}}$ Edição. São Paulo. Editora Saraiva. 2012

LOPES, Maurício Antônio Ribeiro. Princípio da Legalidade Penal. São Paulo. Editora RT. 1994

LOPES, Maurício Antônio Ribeiro. Princípios Penais Constitucionais: O Sistema das Constantes Constitucionais. RT, Fascículos Penais, Ano 89, v. 779. RT: São Paulo. 2000.

Ney Moura Teles, Direito Penal: parte especial, São Paulo, Atlas, 2004, v. II

NORONHA, E. Magalhães.Direito Penal v.1. Introdução e Parte Geral. 29. ed. São Paulo: Saraiva, 1991.

NUCCI, Guilherme. Código Penal Comentado. 9a Edição. São Paulo: Revista dos Tribunais. 2008.

NUCCI. Guilherme de Souza. Manual de Direito Penal - Parte Geral. $7^{\mathrm{a}}$ Edição. São Paulo. Editora Revista dos Tribunais. 2011

QUEIROZ, Paulo. Curso de Direito Penal. Volume 1. Parte Geral. Editora Juspodivm, 2013. 
ROUSSEAU. Jean-Jacques. Do Contrato Social. Edição Ridendo Castigat Mores. Pág.30. Fonte Digital: www.jahr.org .

ROXIN, 1997 apud BITENCOURT, Cezar Roberto. Tratado de Direito Penal: Parte Geral 1. 14.ed. São Paulo: Saraiva, 2009.

ROXIN, Claus. ARTZ,G., e TIEDEMANN, K. Introducción al Derecho Penal y al Derecho Procesal Penal. Barcelona, Ariel,1989.

SANTORO FILHO, Antonio Carlos. Fundamentos de Direito Penal. São Paulo. Malheiros Editora. 2003.

ZAFFARONI, Eugenio Raúl; PIERANGELI, José Henrique. Manual de Direito Penal Brasileiro: Parte Geral. 5. ed. rev. e atual. São Paulo: Revista dos Tribunais, 2004.

Portal virtual Supremo Tribunal Federal: $\underline{\text { www.stf.jus.br }}$

Portal virtual Superior Tribunal de Justiça: www.stj.jus.br

Portal virtual Tribunal Regional Federal $1^{\mathrm{a}}$ Região: www.trf1.jus.br Portal virtual Tribunal Regional Federal 2ª Região: www.trf2.jus.br

Portal virtual da Organização Internacional do Trabalho: www.oit.org.br

Artigos:

Redução à Condição Análoga à de escravo, na Redação da Lei nº10.803/03. Guilherme Guimarães Feliciano. In RDPPP no25 - abril-maio/2004. Acessado no link:http://jus.com.br/artigos/6727/do-crime-de-reducao-acondicao-analoga-a-de-escravo-na-redacao-da-lei-n-10-803-2003 
O Trabalho em Condições Análogas à de Escravo no Brasil Contemporâneo. Maurício Pessoa Lima. Acessado no link: http://www.oit.org.br/sites/all/forced_labour/brasil/documentos/trabalhoescr avofsm.pdf

BRITO FILHO. José Cláudio Monteiro de. Trabalho com redução do homem à condição análoga à de escravo e dignidade da pessoa humana. Acessado no link: http://pgt.mpt.gov.br/publicacoes/escravo/dignidadetrabalhoescravo.pdf 